\title{
微粒子衝突処理を施た純千タンの表面組織および疲労特性
}

\author{
○野田 翔 (京工繊大) 森田 辰郎 (京工繊大) \\ 中口 英眞 (元京工繊大) 加賀谷忠治（中部大） \\ 宮坂四志男（株式会社不二機販）
}

\section{Microstructure near Surface and Fatigue Properties of FPB-treated Pure Titanium}

\author{
Sho NODA ${ }^{* 1}$, Tatsuro MORITA, Hidemasa NAKAGUTI, \\ Chuji KAGAYA and Yoshio MIYASAKA \\ *1 Dept. Mechanical Engineering, Kyoto Institute of Technology \\ Hashigami-cho 1, Sakyou-ku, Kyoto 606-8585, Japan
}

\begin{abstract}
This study was conducted to investigate influence of Fine-Particle Bombarding (FPB) on the microstructure near the surface and fatigue properties of pure titanium. For comparison, a shot-peened material was used. The results showed that surface hardness and compressive residual stress of the FPBed material were higher than those of the shot-peened material. Furthermore, its microstructure near the surface was greatly fined through dynamic recrystallization and nano-crystallized. As a result, the fatigue strength of the FPBed material was improved more than that of the shot-peened material because propagation of internal cracks to the surface was effectively suppressed by the formed layer.
\end{abstract}

Key Words : Titanium, Fine-Paticle Bombarding, Nano-crystallization, Residual stress, Fatigue

\section{1. 緒 䡒}

ショットピーニングから派生した新たな表面改質法と して, 近年, 微粒子を㣫突させる微粒子衝突処理 $\left(\right.$ FPB ${ }^{(1)}$ 処理）が注目されている. FPB 処理は被処理材の極表面 に集中して塑性変形を生じさせることができるため，そ の表面には動的再結晶による著しい組織の微細化，加工 硬化およひ高 圧縮残留応力が生じ，ショットピーニン グよりも顕著な疲労強度の改善効果か認められる(2).しか しながら，FPB 処理が表面組織に及ぼす影響や，特に同 処理を施した材料における疲労き裂の発生形態について は，必ずしも系統的なデータの蓄積が十分ではない．

そこで本研究では，FPB 処理およびショットピーニン グを施した純チタンに関し，透過型電子顕微鏡（以後， TEM）を用いた表面組織の観察およひ波労試験等を行い， 衝突粒子径の相違力婊面性状やそれに強く依存する渡労 特性に及ほ毛影響こついて系統的から詳細に検討した。 なお，本研究では上記のように被処理材として純チタン を選択したが, これは他材と比較してピーニング処理に ともなう疲労強度の改善効果が顕著なためである.

\section{2. 供試材および実験方法}

元材である純チタン圧延丸棒を，表面性状を調べ るためのボタン型試験片（ $\phi 15 \times 10 \mathrm{~mm})$ およひ度 労試験片（JS Z2274）に機械加工した後, 試験部を エメリ研磨およびバフ研磨により鏡面状に仕上げた。 その後, FPB 処理では最大直径 $50 \mu \mathrm{m}$, またショッ トピーニング（以後，SP）では最大直径 $800 \mu \mathrm{m}$ の 衝突粒子を用いて試験部に各処理を施した. その際, 衝突粒子は高速度鋼製（硬さ1000 Hv）とし，また
噴射圧は 0.5 MPa とした。なお, 上記の処理材以外 に，比較のため末処理材を併せて準備した。

本研究では，まず各処理材の硬さ分布を調べるた め, ボタン型試験片の絴断面上で表面から内部に向 かってマイクロビッカース硬さを試験力 $98 \mathrm{mN}$ の 下で測定した. 残留応力測定にはX 線残留応力測定 装置を用い，また TEMを用いて最表面の組織観察 を行うとともに, 電子線回折により表面組織の微細 化の程度を調べた. 疲労試験は平面曲げとし, 室温・ 大気中において応力比 $\mathrm{R}=-1$, 繰返し速度 $25 \mathrm{~Hz}$ の 条件で行った. また, 破面観察の結果, 処理材のき 裂発生起点が材料内部であったことから, FPB 材に ついては代表例として未破断の試験片の断面観察を 行い，き裂発生直後の状態を詳細に調べた。

\section{3. 実験結果および考察}

3:1 衝突粒子径と表面組織の関係 図 1 に, FPB 材およびSP 材の硬さ分布をまとめて示す．同 図から明らかなように，FPB 材では SP 材と比べて 硬化層厚さは小さいが, 表面近傍の硬さは著しく上 昇していた.このような FPB 材における表面硬さの 上昇は，同処理の場合に塑性变形が極表面に集中す るため, 加工硬化の程度が SP 材よりも大となった 結果である.さらに，上記の事柄は残留応力值にも 反映されており, FPB 材で $337 \pm 99 \mathrm{MPa}, \mathrm{SP}$ 材で 151 $\pm 38 \mathrm{MPa}$ と, 前者において著しく高い㽵縮残留応力 が付与されていた。

図 2 に, 各処理材における最表面の組織観察の結 果およびそれらの電子線回折結果をまとめて示す。 同図に示すように，各処理材の組織はナノ結晶化し 


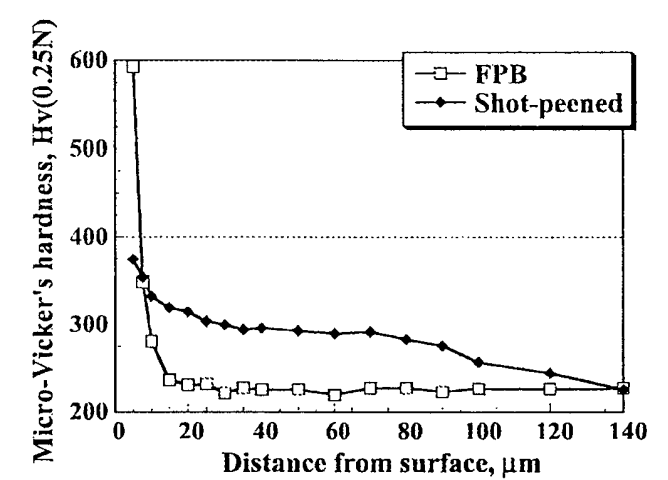

Fig.1 Hardness distributions measured on the cross-section.
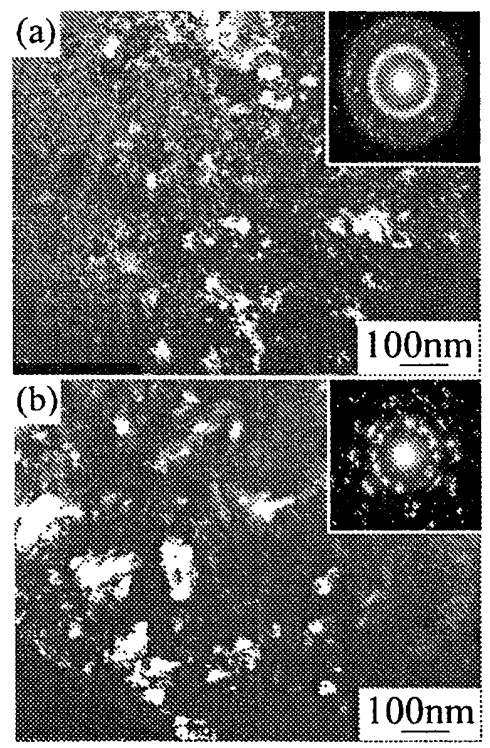

Fig.2 Nano-structure observed near the surface and diffraction pattem of each material :(a)FPBed material, (b)Shot-peened material.

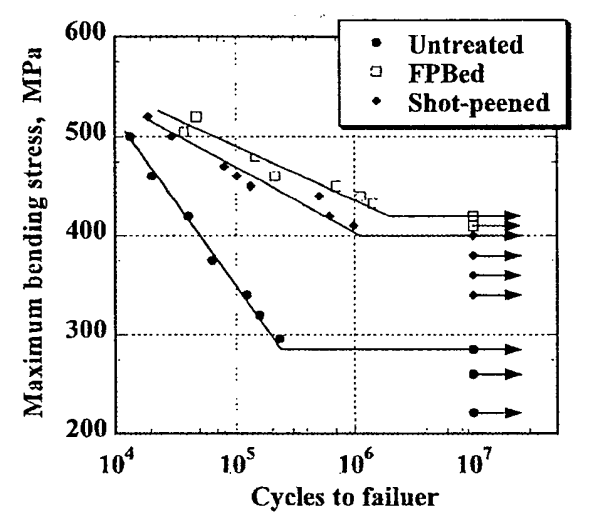

Fig.3 S-N curves.

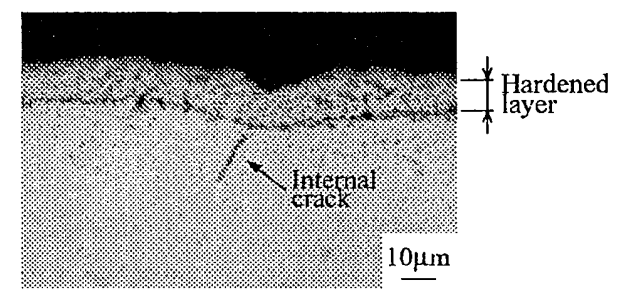

Fig.4 Internal crack observed on the cross-section of the FPBed material before its final fracture $\left(\sigma_{\mathrm{a}}=510 \mathrm{MPa}\right)$.
ていた。しかしながら，FPB 材の組織は SP 材の場 合に比べてより微細かつ一様であった.このことは, FPB 材の回折図形では SP 材の場合よりも明瞭なり ング状となっていたことからも理解される.

3 - 2 表面層性状と疲労強度の関係 図 3 に, 各材の S-N 曲線をまとめて示す. 同図から理解され るように, 未処理材の疲労強度に対して FPB 材で $47 \%$ ，また SP 材では $40 \%$ と疲労強度は大幅に改善 された. そのような疲労強度の改善は, 硬化層の形 成により表面からのき裂発生が抑制されたためであ る.しかしながら，この考察では FPB 材と SP 材と の疲労強度の差異を十分に説明されていない。

そこで上記の点を明確にするため，FPB 材および $\mathrm{SP}$ 材について疲労試験後に破面観察を行った. その 結果, き裂の発生起点は明らかに表面層下であった. 実際，FPB 材について未破断の試験片の断面を詳細 に観察したところ，図 4 に示すように表面層の直下 まで進展した微小な内部き裂が観察された。これら の観察結果から，ピーニング材 (FPB 材， SP 材) に おいてはまず表面層下でき裂が発生した後，そのき 裂が表面層を突破することで破断に至ったといえる。

以上より，ピーニング材の疲労寿命および度労強 度は表面層が内部き裂の進展を抑制する効果の程度 によって決定されると考えられる. 同観点からすれ ば, 硬化層厚さが小さいにもかかわらずFPB 材にお いて疲労強度の改善率が高かったのは，前節で説明 したように表面近傍の硬さが高いだけでなく表面組 織の微細化の程度が著しく，さらに高い圧縮残留応 力が付与されたため, 内部き裂が表面一進展するこ とがより強く抑制されたためであるといえる.

\section{4. 結}

(1) FPB 材では SP 材の場合と比べて硬化層厚さは小 さかったが，表面近傍の硬さは著しく上昇し，また 圧絔残留応力值も高かった.さらに, FPB 材では SP 材の場合よりもナノ結晶化の程度が顕著であった.

(2) FPB およびSP 処理にともない純于タンの疲労強 度は大幅に改善された。また，両材では表面層下で き裂が発生した後，そのき裂が表面層を突破するこ とで破断に至ることが明らかとなった.このことか ら, ピーニング材の疲労寿命およひ疲労強度は表面 層が内部き裂の進展を抑制する効果の程度によって 決定されると考えられた。

(3) SP材よりも硬化層厚さが小さいFPB 材において 疲労強度の改善率が高かった。これは, FPB材にお いて表面近傍の硬さが高いだけでなく表面組織の微 細化の程度が著しく，さらに高い圧縮残留応力が付 与されたため, 内部き裂の表面への進展がより強く 抑制されたためと考えられた。

\section{文 献}

(1) C.Kagaya, Journal of the Japan Society of Precision Engineering, 72(9), 1067-1070, (2006).

(2) KTakao, M.Sogoh and K.Matumoto, Transactions of the Japan Society of Mechanical Engineers A, 52(484), 2574-2578, (1986). 